Institute for Medical Research and at its Radiobiology Unit, and clinical trials in such fields as cancer treatment, NMR imaging and multiple sclerosis.

The board recommends that MRC should "review" its participation in the European Molecular Biology Laboratory (Heidelberg), warns the council not to spend research funds in neglectful universities and recommends that the council should have a constant 22.5 per cent of the science budget, amounting to $£ 113$ million next year which will be increased by about f5 million from other sources.

The Natural Environment Research Council (NERC) plans to support more university research and graduate students, and to continue diverting resources towards remote sensing. Participation in the international ocean drilling programme beyond 1983 is uncertain, given the likely 50 per cent increase of cost.

The board recommends a share of the science budget rising from $£ 58$ million in $1983-84$ to $£ 63$ million in $1985-86$, including a constant $£ 0.4$ million for ocean drilling. At the end of the period, NERC will be $£ 1.7$ million worse off than now, but will earn $£ 29$ million from commissioned research.

The Science and Engineering Research Council (SERC) plans to increase support for biotechnology and civil engineering, to cut back in marine technology and polymer engineering, to reduce its payroll by 1 per cent in each of the next three years and to divert resources of two "major new programmes" - information technology and space research, perhaps at a total cost of $£ 50$ million over three years.

The board accepts that the time has come to halt the decline of "big science", recommends that the council should have an extra $£ 22.5$ million over three years to support basic research in information technology but that it should find the extra needed from its own resources. The board says that the council's budget should in-

Age distribution in British academic disciplines.
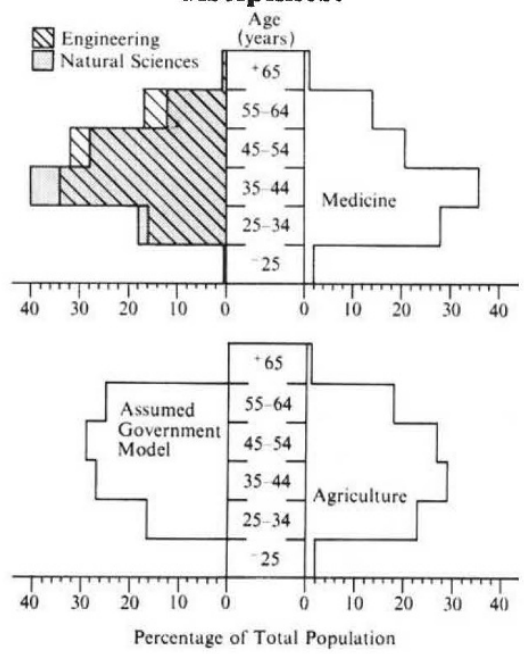

Data from the $A B R C$ report showing age distribution in various disciplines together with the steady-state distribution (bottom, left).

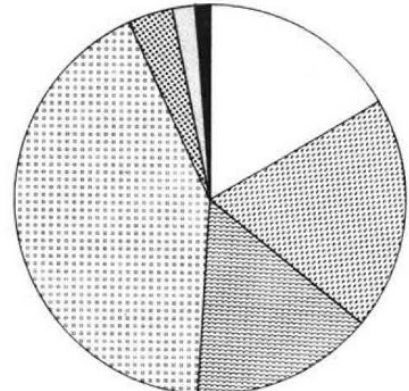

Agricultural Research Council

Medical Research Council

Natural Environment Research Council

Science and Engineering Research Council

Social Science Research Council

British Museum (Natural History)

Royal Society

Relative income of research councils, etc. in 1982-83. Figures include allocations from the science budget, commissioned research and other receipts. Total income is $£ 579$ million. (Source: The Science Budget, a Forward Look, the Advisory Board for the Research Councils.)

crease from $£ 234$ million now to $£ 250$ million next year and $£ 278$ million in three years, to which is added about $£ 10$ million in other income.

The Social Science Research Council (SSRC) pleads for a restoration of the funds cut from its budget in recent years, promising new research training schemes and boasting of a smoother organization. The board's recommendation accepts this case, suggesting a share of the science budget rising from $£ 23.3$ million next year to $£ 25.5$ million after three years. These are the sums from which the Secretary of State for Education and Science has subtracted in advance a total of $£ 6$ million. Sir Alec Merrison said last week that his board had no hard feelings on the subject, saying that the minister was the one with ultimate responsibility.

The British Museum (Natural History) asked the board for a general increase of funds to strengthen its general programme, and has been repaid with the recommendation that the proposed extension of the museum's exhibition space (at a cost of between $£ 23$ and $£ 29$ million) should be abandoned. The board says that the project, "however worthy, has no direct connection with scientific research". The Royal Society plans to spend $£ 1$ million a year on a scheme for 100 new research fellowships and asks for half that amount to support exchanges with the United States, while promising stronger collaboration with Japan. (The society laments that the Australian government is unwilling to help with the cost of the present Anglo-Australian exchange scheme.)

The board accepts the case that money should be spent on people rather than on instrumentation and project grants, and recommends an increase of $£ 0.5$ million in the society's budget to $\mathrm{f5.0}$ million next year rising to $£ 5.8$ million in $1985-86$. The society's total annual income is nearly $£ 2$ million greater

\title{
Environmental research at risk
}

Oceanography and forestry departments in British universities may be threatened by university efforts to trim spending in line with government cuts, according to Sir Hermann Bondi, chairman of the UK Natural Environment Research Council (NERC).

"It is of the utmost importance"' writes Sir Hermann in the 1982 annual NERC report (HMSO, £4.25), published last week "that [the universities] manage their affairs in their present difficulties so as not to weaken their research capabilities ...". Small fields, common to only a few universities, are particularly vulnerable, believes Sir Hermann - and he is clearly itching to tell the universities what to do without quite daring to. "Our ability to intervene and to help is clearly very limited" he writes. NERC has offered to help relocate departments from one university to another and to allow a degree of rationalization of resources in the universities - "but we must wait for their initiative ...".

Sir Hermann has also had to wait for the initiative of certain government departments, not named in the report but certainly including the Department of the Environment, which have been very slow to define a long-term contract research policy. "Some of our customers find talking to us a little strange" said Sir Hermann last week. The strangeness is legal: advice has been given that a verbal agreement is as binding as a written one, with the result that "certain departments" have refused to discuss possible future funding or policy. This has led to considerable difficulties at NERC, which must assume that it always has the correct programme of basic research to provide expertise for any applied contracts that may be placed with it.

The Rothschild principle, where a portion of a research council's cash is obtained by contract from a customer department, was still "fundamentally right" said Sir Hermann. However, being right in principle was not sufficient - the department itself had to have great scientific competence. One of Rothschild's objectives had been to create that competence in the form of chief scientists' divisions - but in some departments the chief scientists had been pushed to one side. "They must be at the centre of decision-making" said Sir Hermann. The scientific attitude of the chief scientist should "permeate the whole department', $\quad$ Robert Walgate 